\title{
PENGEMBANGAN PETERNAKAN SUSU NASIONAL MELALUI KELEMBAGAAN EKONOMI BARU
}

\author{
Karuniana Dianta A. Sebayang*
}

\begin{abstract}
The aim of this paper is to analyze the dairy farmers problems who have to face the gap between demand and supply milk issues. Demand for milk commodities increased significant year by year, but the national milk production can not supply the milk processing industry needs. Local fresh milk production only supply $25 \%$ of the raw material for the milk processing industry.

The New Institutionalism in Economic and Sociology model regards a mechanisms for the integration of formal and informal relationships at every level causal, like at the micro level (individual), meso (group or organization) and the macro level in the form of environmental policy (policy environment) which affect the system development and agribusiness.

This study aims to generate the government policy which should be able to increase the bargaining power of dairy farmers in development their agribusiness through the strengthening of economic and social capital to create competitive dairy farmers.
\end{abstract}

Keywords: Milk farmers, New Institutional Economics, New Institutionalism in Economic and Sociology, Public Policy

\section{PENDAHULUAN}

Sektor pertanian merupakan salah satu sektor yang memberikan kontribusi besar pada perekonomian Indonesia dan juga merupakan salah satu sumber penghidupan bagi sebagian penduduk Indonesia. Salah

* Karuniana Dianta A. Sebayang. Dosen Fakultas Ekonomi Universitas Negeri Jakarta satu sub sektor pertanian yang berkembang cukup pesat adalah sektor peternakan. Seiring dengan perkembangan kebutuhan susu masyarakat, pemerintah makin memperhatkan sub sektor yang memiliki potensi pengembangan yang besar. Pemberdayaan sistem agribisnis khususnya peternakan susu baik dari hulu hingga hilir 
sehingga bisa membantu menciptkanan lapangan kerja dan nilai tambah dalam perekonomian terutama sektor pertanian secara umum dan khususnya bagi keluarga pedesaan, baik petani kecil maupun buruh tani yang tidak memiliki tanah.

Permintaan terhadap komoditi susu teritama susu siap minum dari tahun ke tahun terus mengalami peningkatan, tetapi produksi susu nasional belum mampu mencukupi kebutuhan konsumsi masyarakat Indonesia. Produksi susu segar lokal hanya memenuhi kebutuhan 25\% dari kebutuhan bahan baku IPS dalam memenuhi kebutuhan susu siap minum masyarakat. Oleh karena itu pemerintah mengeluarkan kebijakan untuk melakukan impor susu dari luar negeri. Selain melakukan impor pemerintah juga melakukan ekspor susu dalam bentuk susu olahan.

Pengembangan usaha sapi perah merupakan salah satu alternatif dalam rangka pemenuhan gizi masyarakat serta pengurangan tingkat ketergantungan nasional terhadap impor susu. Sebenarnya usaha persusuan di Indonesia sudah sejak lama dikembangkan sejak tahun 1977 ditandai oleh SKB 3 mentri tetapi belum bisa berbicara banyak dalam menstimulasi produki susu lokal dengan memberikan bantuan pengelolaan peternakan susu sapi perah. Seiring dengan perkembangan waktu, perkembangan persusuan di Indonesia dibagi menjadi tiga tahap perkembangan, yaitu Tahap I (periode sebelum tahun 1980) disebut fase perkembangan sapi perah, Tahap II (periode 1980 1997) disebut periode peningkatan populasi sapi perah, dan Tahap III (periode 1997 sampai sekarang) disebut periode stagnasi. ( Lilis Nulina,2005).

Namun

keberhasilan peternakan sapi sangat tergantung pada manajemen yang efektif

seperti pemasaran susu, karena

pemasaran menyediakan stimulus untuk berproduksi lebih banyak sehingga peningkatkan permintaan, insentif sendiri untuk meningkatkan pasokan. Hasil sistem pemasaran yang efisien dalam peningkatan penjualan yang lebih tinggi akan mempengaruhi keputusan produsen untuk menginvestasikan sumber daya lebih dalam kegiatan ekonomi tersebut dalam periode waktu tertentu. Sebuah sistem pemasaran yang efisien juga membantu membawa produk berkualitas 
kepada konsumen dengan biaya serendah mungkin. (Debnarayan Sarker, 2010)

Pemberlakukan Peraturan Menteri Keuangan (PMK) Nomor: 101/PMK.001/2009 tentang Tarif Bea Masuk sebesar lima persen terhadap impor tujuh produk susu tertentu yang terdiri dari 6 produk "Full Cream Milk Powder" (FCMP) dan 1 produk susu mentega. Kebijakan itu mengubah kebijakan sebelumnya, yaitu PMK Nomor: 19/PMK.011/2009 pada 13 Februari 2009 yang tidak dikenai biaya atau $0 \%$. Peraturan Menkeu yang sebelumnya, sesuai dengan peraturan World Trade Organitation (WTO) yaitu bea masuk susu impor akan menjadi nol persen pada tahun 2017. Meskipun demikian, kenaikan tarif menjadi lima persen tersebut tidak serta merta memperbaiki taraf hidup peternak sapi.

Dengan adanya perdagangan bebas, produk susu segar impor dapat memasuki pasaran Indonesia dengan mudah. Satu sisi, hal ini dapat memberikan peluang dan kesempatan pada konsumen untuk memilih produk susu yang mereka inginkan sesuai dengan kualitas dan harga yang dapat mereka jangkau. Tapi di sisi lain, hal ini dapat menyebabkan keterpurukan bagi para peternak sapi perah karena ketidakmampuan bersaing dalam sisi harga, kualitas, dan produksi susu dibandingkan dengan susu impor. Kondisi inilah yang menyebabkan para peternak sapi perah kembali tidak bergairah untuk meneruskan usaha peternakan sapi perahnya. Hal ini di perparah dengan belum seimbangnya antara biaya roduksi dengan harga beli susu segar yang peternak dapat dari IPS.

Pada kenyataannya usaha peternakan sapi perah rakyat ini dihadapkan dalam dua masalah besar, yaitu (1) masalah zooteknik dalam menghadapi pasar global seperti strategi produk, teknologi, pelatihan, biaya riset dan pengembangan dan faktor lingkungan alam. (2) serta masalah kelembagaan sosial ekonomi yang berkaitan dengan lingkungan bisnis (pajak, suku bunga, nilai tukar uang), kebijakan perdagangan, kebijakan riset dan pengembangan, serta pendidikan, pelatihan dan regulasi, kebijakan harga input dan kuantitas permintaan domestik kurang mendukung terhadap kinerja usahanya. Kedua aspek tersebut, seperti lingkaran setan yang saling berkaitan sehingga mengakibatkan perkembangan usaha peternakan 
rakyat dalam kurun waktu dua puluh tahun ini seperti jalan di tempat.

Dalam dinamika peternakan sapi perah lokal dalam era globalisasi ini sangat dipengaruhi oleh peran kebijakan pemerintah untuk membangun sistem peternakan lokal yang mampu bersaing dan berdaya saing dalam menghadapi susu impor. Daya saing peternak lokal masih sangat lemah hal ini terjadi karena kualitas dan kuantitas susu yang belum mampu bersaing karena kebijakan pemerintah belum sepenuhnya bisa mengembangkan sektor peternakan susu perah selain itu pasar produk susu segar di Indonesia cenderung memiliki struktur pasar oligopsoni dengan Industri Pengolahan Susu (IPS) sebagai konsumen utama (Hutagaol dan Karo-Karo, 2009), hal tersebut juga didukung bahwa koperasi susu dan peternak memiliki posisi tawar yang lemah dalam memasok dan menentukan harga susu kepada IPS. Lemahnya posisi tawar peternak terhadap IPS yang lebih cenderung untuk menggunakan bahan baku impor merupakan salah satu kendala utama. Hal ini menimbulkan resiko yang besar dalam usaha ternak sapi perah dimana hukum permintaan dan penawaran berlaku dalam penentuan harga susu.

Dari paparan garis besar masalah yang dihadapi, tentu saja hal tersebut merupakan satu tantangan tersendiri bagi para pelaku ekonomi Indonesia terutama bagi pemerintah untuk membuat dan memberlakukan kebijakan yang berkaitan dengan kebijakan kelembagaan ekonomi dan sosial untuk menopang usaha peternakan rakyat agar mampu berdaya saing yang pada akhirnya bisa meningkatkan kesejahteraan masyarakat khususnya para peternak.

\section{Kelembagaan \\ Definisi Kelembagaan}

Doglas North (1990) seorang sejarawan ekonomi terkemuka mendefinisikan kelembagaan sebagai batasan-batasan yang dibuat untuk membentuk pola interaksi yang harmonis antara individu dalam melakukan interaksi politik, sosial dan ekonomi.

Ostrom (1990) mengartikan kelembagaan sebagai aturan yang berlaku dalam masyarakat yang menentukan siapa yang berhak membuat keputusan, tindakan apa yang boleh dan tidak boleh dilakukan, aturan apa yang berlaku 
umum di masyarakat, prosedur apa yang harus diikuti, informasi apa yang mesti atau tidak boleh disediakan dan keuntungan apa yang individu akan terima sebagai buah dari tindakan yang dilakukannya. Singkatnya, kelembagan adalah aturan main yang berlaku dalam masyarakat yang disepakati oleh anggota masyarakat tersebut sebagai sesuatu yang harus diikuti dan dipatuhi (memiliki kekuatan sanksi) dengan tujuan terciptanya keteraturan dan kepastian interaksi di antara sesama anggota masyarakat. Interaksi yang dimaksud terkait dengan kegiatan ekonomi, politik maupun sosial.

Berdasarkan atas bentuknya (tertulis/tidak tertulis) North (1990) membagi kelembagaan menjadi dua: informal dan formal. Kelembagaan informal adalah kelembagaan yang keberadaannya di masyarakat umumnya tidak tertulis. Adat istiadat, tradisi, pamali, kesepakatan, u zw32xkonvensi dan sejenisnya dengan beragam nama dan sebutan dikelompokan sebagai kelembagaan informal. Sedangkan kelembagaan formal adalah peraturan tertulis seperti perundang-undangan, kesepakatan (agreements), perjanjian kontrak, peraturan bidang ekonomi, bisniss, politik dan lain-lain. Kesepakatankesepakatn yang berlaku baik pada level international, nasional, regional maupun lokal termasuk ke dalam kelembagaan formal.

Wolfgang Kasper dan Manfred Streit (1998) membagi kelembagaan berdasarkan atas proses kemunculannya menjadi dua, yaitu internal dan external institution. Internal institution adalah institusi yang tumbuh dari budaya masyarakat seperti nilai-nilai kearifan lokal yang hidup di masyarakat. External institution adalah institusi yang dibuat oleh pihak luar/ketiga yang kemudian diberlakukan pada suatu komunitas tertentu. Regulasi produk pemerintah termasuk external institution.

$$
\text { Uphopff }
$$
mengkasifikasi institusi ke dalam tiga kelompok, yaitu institusi yang bukan organisasi, institusi yang organisasi dan sebaliknya (organisasi juga institusi), dan organisasi yang bukan institusi. Sistem kepemilikan lahan (land tenure system), hukum, pernikahan, uang, dan daya tawar kelompok (collective bargaining power) merupakan contoh kelompok 
pertama; keluarga, mahkamah agung, dan bank nasional (seperti Bank Indonesia) contoh yang kedua; dan bank daerah, perusahaan dan organisasi penyedia jasa konsultan merupakan contoh organisasi yang bukan institusi.

Menurut Wiliamson (2000), yang dimaksud kelembagaan formal adalah kelembagaan yang dibentuk melalui perundang-undangan (konstitusi) yang dibuat oleh lembaga legislatif/pemerintah. Namun demikian, hal ini bukan merupakan kriteria mutlak, karena banyak kasus kelembagaan formal yang merupakan hasil evoluasi dari kelembagaan informal sebagaimana undang-undang perikanan di Jepang yang berasal dari hukum adat atau tradisi yang hidup dan menyatu dalam masyarakat selama ratusan tahun.(Ruddle,1993)

\section{Ekonomi Kelembagaan ( Old Institutional Economics)}

Kemunculan wacana ekonomi kelembagaan diawali dengan kritik pedas Thorsten Veblen atas dasar teori dan implementasi ekonomi klasik dan neoklasik. Sebagaimana diuraikan sebelumnya, main stream ekonomi (neoklasik dan klasik) sejak digagas pertama kali oleh Adam Smith menempatkan manusia sebagai makhluk super rasional. Konsekuensi dari pemikiran ini, manusia dianggap sangat rasional dalam menentukan pililihan-pilihan dalam memenuhi kebutugan hidupnya. Teori utilitas yang memandang Veblen menentang penadapat ini. Menurutnya, manusia tidak hanya memiliki rasio tapi juga memiliki perasaan, kecenderungan, instink, dan kebiasaan yang terikat dengan budayanya. Pililihan-pilihan dalam memenuhi kebutuhan hidup tidak semestinya hanya didasarkan atas pertimbangan rasional seraya mengabaikan dimensi lain dari manusia. Memandang manusia hanya sebagai makhluk rasional terlalu menyederhanakan persoalan manusia. Manusia melakukan kegiatan tidak hanya karena motif ekonomi. Ia memiliki instink/dorongan untuk melakukan kerja. Veblem membagi kelembagaan menjadi dua: kelembagaan teknologi dan kelembagaan seremonial. Kelembagaan teknologi meliputi mesin pengolah (machine process), penemuan, metoda produksi, teknologi dll. Kelembagaan seremonial meliputi serangkaian hak-hak kepemilikan (set of property rights), struktur sosial dan ekonomi, kelembagaan keuangan, 


\begin{tabular}{|c|c|}
\hline Perubahan & kelembagaan \\
\hline $\begin{array}{l}\text { teknologi akan } \\
\text { perubahan }\end{array}$ & $\begin{array}{r}\text { mendorong } \\
\text { kelembaqaan }\end{array}$ \\
\hline
\end{tabular}

Secara khusus Veblen menyebutkan bahwa teknologi merupakan bagian dari kelembagaan, dimana teknologi sangat berpengaruh pada cara pandang dan perubahan sistem sosial dan ekonomi. Sebagai contoh, masyarakat handphone yang pada awalnya hanya dianggap sebagai alat komunikasi untuk menelpon, lanjut menjadi menelpon dan mengirim teks, tambah lagi fungsi main game, dan internet, maka melaui setiap perubahan pada teknologi mengakibatkan perubahan cara pandang dan perubahan sistem dan ekonomi, seperti sekarang bisa melalukan e-banking, booking online via handphone, dsb.

\section{Ekonomi Kelembagaan Baru (New Institutional Economics)} American Institutionalist School menganggap kelembagaan sosial merupakan dasar penentu struktur ekonomi, berbeda dengan teori ekonomi neoklasik yang menganggap bahwa struktur ekonomi hanya didasari oleh mekanisme pasar. Sedangkan Chicago School berpendapat bahwa kelembagaan

Institutional)

baru

(New

sekumpulan

merupakan

menjelaskan struktur ekonomi tidak hanya didasari oleh mekanisme pasar saja tetapi juga dipengaruhi oleh fenomena aktifitas manusia dan kelembagaan sosial.

NIE berkembang pesat dan mulai diperhitungkan sebagai teori ekonomi alternatif setelah Ronald Coase (1960) menemukan konsep biaya transaksi (transaction cost). Menurutnya, biaya transaksi mempengaruhi kelembagaan dan pilihan-pilihan ekonomi yang orang lakukan.

Selain itu, perkembangan NIE juga diperkuat dengan lahirnya paradigma hak kepemilikan (property rights) oleh Harold Demsetz yang berargumen bahwa effisiensi alokasi sumberdaya sangat ditentukan oleh faktor kepemilikan (property rights) sebagai sebuah lembaga (institusi). Dengan kata lain, menurutnya, institusi pasar dapat bekerja mengalokasi sumberdaya yang terbatas dengan baik bila ada alokasi hak kepemilikan (property rights). (Williamson, 2000)

Kelembagaan Ekonomi dan Sosiologi Baru (New 
Institutionalism in Economy and Sociology)

Pemikiran Victor Nee (2005) mengenai New Institutionalism in Economy and Sociology diawali dengan gagasannya tentang new institutional economics yang berinteraksi dengan jaringan sosial (social network) dan norma-norma sosial dalam mengarahkan tindakantindakan ekonomi.

Nee menjelaskan bahwa dalam sistem ekonomi aktor ekonomi bukan merupakan atom yang terlepas dalam konteks masyarakat, dan hubungan sosial, tetapi juga ada hubungan antara institusi formal dan makro yang melahirkan kepercayaan dalam kegiatan ekonomi tersebut yang merupakan bentuk tanggapannya pada pendekatan New Institusonal Economic yang dikemukakan Williamson. (Granovetter, M. 2005) Pandangan ini juga merupakan tanggapan dari padangan Granovetter (2005) dimana dia hanya menjelaskan bahwa kegiatan ekonomi bahwa aktor ekonomi merupakan bagian dari hubungan sosial dalam mengejar kepentingan ekonomi tanpa menjelaskan bahwa hal tersebut juga dipengaruhi oleh instusi formal yang menciptakan ketaatan dalam kegiatan ekonomi.

Berlandaskan kepada kritik terhadap pendekatan New Institutional Economic dan mencermati pandangan Garnovetter di atas, Nee (2005) mengemukakan model institusional baru dari perspektif Sosiologi dan Ekonomi. Model yang memandang mekanisme institusional memiliki penyebab yang lebih dalam karena sangat menentukan insentif dan penghargaan. Dalam pandangan New Institusional Sosiologi Ekonomi, norma-norma yang ada akan berinteraksi melalui peraturan formal (formal rules) dalam merealisasikan kepentingan individu dalam kegiatan ekonominya.

Nee (2005) mengemukakan adanya mekanisme integrasi hubungan formal dan informal pada setiap level kausal, yakni pada tataran mikro (individu), meso (kelompok ataupun organisasi), dan tataran makro berupa lingkungan kebijakan (policy environment), termasuk ketentuan dalam pengembangan sistem dan usaha agribisnis. 
Gambar 1.1

Model New Institutionalism in Economy and Sociology

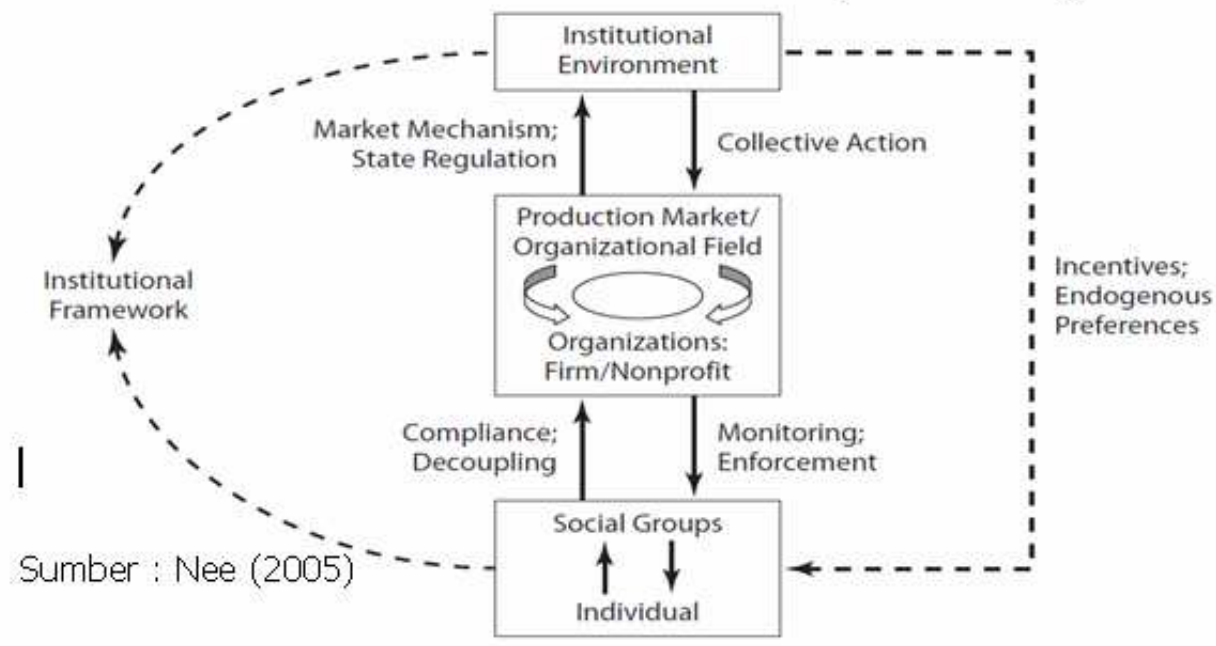

Model multi level di atas menerangkan mengenai keterkaitan fungsi lingkungan institusional berupa regulasi formal yang diterapkan oleh pemerintah (policy environment) dalam menata hak-hak kepemilikan, menata pasar, dan perusahaan, yang berintegrasi dengan aturan formal dan informal di level meso (organisasi) dan juga pada level mikro (grup sosial dan individu) dalam kegiatan ekonominya.

Model ini memandang mekanisme institusional memiliki penyebab yang lebih dalam karena sangat menentukan insentif dan penghargaan, sedangkan dalam pandangan New Institusional, norma-norma yang ada akan berinteraksi dengan hukum formal (formal rules) dalam merealisasikan kepentingan individu.

Nee (2005) mengemukakan terjadi mekanisme integrasi hubungan formal dan informal pada setiap level sebab akibat (kausal), yakni pada tataran mikro (individu), meso (kelompok ataupun organisasi), dan tataran makro berupa lingkungan kebijakan (policy environment).

Pada intinya Lin (2000) membahas mengenai ketidakmerataan (inequality) pada modalmodal sosial dengan mengukur dan menganalisa dinamika baik berupa faktor pendukung maupun faktor penghambat dalam bidang struktural dengan dinamika norma- 
norma sosial yang terjadi dalam interkasi sosial di masyarakat. Apabila integrasi itu tidak berjalan sesuai dengan harapan, maka kemungkinan ada kecenderungan terjadi ketidakmerataan perlakuan pada sumber-sumber sosial seperti yang dikemukakan Lin.

Lin (2000) menjelaskan fenomena ketidakmerataan (inequality) modal sosial bisa terjadi apabila aktor atau individu maupun komunitas dapat mengakumulasikan dan menguasai sumber daya yang meliputi modal fisik seperti lahan, uang dan alat produksi lainnya, serta modal non fisik.

Ketidakmerataan sumber

daya (termasuk jaringan sosial) dapat menyebabkan ketidakmerataan sosial (social inequality). Lin (2000) mengemukakan definisi modal sosial sebagai investasi yang dapat dimanfaatkan dalam mencapai hasil yang diharapkan, dan investasi itu tertambat (embedded) dalam relasi sosial. Lebih lanjut dikemukakan bahwa modal sosial bisa dibedakan dalam dua konsep, pertama bahwa sumber modal sosial dapat diakses pada relasi sosial, dan konsep kedua menjelaskan bahwa ada penekanan mengenai lokasi atau sumber modal sosial berada pada jaringan sosial atau karateristik jaringan sosial.

Pada tataran empiris, beberapa studi secara meyakinkan menemukan bahwa sumber daya sosial berpengaruh terhadap pencapaian hasil kegiatan seperti pada kegiatan mencari pekerjaan, promosi, dan kegiatan memenuhi nafkah. Bahkan beberapa studi secara empiris juga menyatakan sumber daya sosial sangat berpengaruh terhadap pencapaian peningkatan status sosial ekonomi.

Lebih lanjut, Lin (2000) mengemukakan proposisi bahwa semakin baik posisi dalam kelompok organisasi, atau komunitas maka semakin baik juga peluang dalam mengakses dan memanfaatkan sumber daya sosial. Demikian halnya mengenai proposisi bahwa semakin kuat jaringan sosial (semakin Iemah ikatan sosial) akan berasosiasi positif dengan sumber daya sosial.

\section{PEMBAHASAN}

Produksi susu segar dalam negeri merupakan komoditi yang potensial, tetapi sampai saat ini produksi susu dalam negeri hanya bisa memenuhi sekitar 30\% kebutuhan dalam bahan baku IPS di dalam negeri. Hal ini dikarenakan para peternak masih mengalami 
berbagai permasalahan antara lain dalam hal menyangkut masalah kesehatan dan mutu bibit ternak, modal, lahan sebagai sumber rumput hijauan bagi ternak, tingginya biaya transportasi, serta kecilnya skala usaha dan kesemuanya itu mengakibatkan makin rendahnya mutu susu yang tidak memenuhi standar bagi IPS. Peternak membutuhkan perlindungan dan bantuan dari pemerintah untuk bisa berdaya saing. Untuk mengatasi masalah ini pemerintah sudah seharusnya membuat kebijakan yang sinergis antar lembaganya sehingga bisa mendorong para peternak mampu berdaya saing, terutama pembentukan kebijakan yang bisa mengatasi masalah kelembagaan ekonomi sosial yang berkaitan erat dengan usaha peternakan lokal.

$$
\text { Kebijakan Pemerintah }
$$

Indonesia baru-baru ini seperti keputusan menteri keuangan tentang pembebasan bea masuk bagi bahan baku susu impor, kebijakan ini tidak berpihak pada peternak dan menyebabkan harga susu tidak terjangkau oleh masyarakat bawah. Kebijakan tentang susu tersebut hanya ditujukan untuk kepentingan perusahaan-perusahaan multinasional. Saat ini jumlah koperasi susu perah di Indonesia mencapai 340.000 unit dan 120.000 peternak yang rata-rata memiliki tiga hingga empat ekor sapi, sedangkan produksi susu nasional hanya memenuhi permintaan domestik $25 \%$ dari jumlah konsumsi sekitar 700.000 ton per tahun, sisanya dipenuhi dari impor.

Sebelumnya Indonesia mempunyai kebijakan untuk melindungi peternak susu dalam negeri lewat Surat Keputusan Bersama (SKB) Tiga Menteri yaitu Menteri Pertanian, Menteri Perindustrian, dan Menteri Perdagangan dan Koperasi pada tahun 1983. Saat itu, Industri Pengolahan Susu (IPS) diwajibkan untuk membeli susu dari peternak lokal disamping susu impor sebagai bahan baku Industrinya. Di sisi lain, penerapan SKB ini menimbulkan ketergantungan peternak kepada IPS-IPS. Petani tidak punya hak untuk menentukan harga. Yang berhak menentukan harga dan kuota susu dari peternak hanya IPS. Akibat dari SKB itu hingga kini para peternak masih memiliki ketergantungan pada IPS yang menyerap susu hasil produksi mereka sebesar 90 persen.

Masalah yang dihadapi oleh 
peternak bukan hanya harga susu yang rendah dan tidak bisa menutupi biaya produksi, peternak juga memiliki masalah dalam bidang permodalan dimana tambahan modal sangat sulit di dapat oleh peternak selama ini hanya koperasi saja yang memberikan kredit tapi jumlahnya sangat terbatas sehingga kurang mampu untuk mengembangkan usaha peternakan, sedangka bantuan penguatan modal dari pemerintah tidak bisa mereka dapatkan karena sulitnya birokrasi dan sebagai jalan keluarnya para peternak mengambil kredit melalui bank komersial dengan bunga yang sangat tinggi. Dari segi kredit tidak ada dukungan dari pemerintah dengan sistem kredit yang sistem koleteralnya berpihak pada peternak.

Masalah peternak tidak hanya itu, peternak juga menghadapi masalah pembibitan dimana bibit yang berkualitas sulit di dapat dan harganya yang terlalu mahal untuk dijangkau sebagaian besar peternak. Masalah lahan sebagi sumber hijauan menjadi masalah yang sangat krusial karena sebagaian besar lahan di daerah peternakan sekarang telah digunakan untuk daerah wisata dan perumahan, lahan yang dipinjamkan oleh pemeritah letaknya jauh sehingga membebani peternak dengan biaya transportasi dan pengawasan.

Di berbagai negara maju, peternak itu pasti dilindungi oleh berbagai macam kebijakan pemerintah. Namun, untuk pemerintah Indonesia hingga kini kebijakan yang pro peternak dan petani itu belumlah terjadi. Kebijakan pemerintah saat ini terutama masalah kebijakan kelembagaan ekonomi sosial belum bisa mengatur besarnya omzet dari peternakan susu segar dari peternak lokal yang menjadi andalan para peternak dan belum ada pengembangan kebijakan serius mengenai hal tersebut.

Pemerintah juga belum membuat kebijakan mengenai pengembangan usaha pembibitan sapi ideal yang di arahkan pada kawasan khusus ataupun kawasan terintegrasi dengan komoditi lainnya serta terkonsentrasi pada suatu wilayah untuk mempermudah pembinaan, bimbingan, dan pengawasan dalam pengembangan usaha pembibitan sapi perah yang baik (good breeding practice) yang sejalan dengan kebijakan swasembada susu yang di gadanggadang pemeritah. 
Dengan adanya kebijakan yang mengatur megenai pengembangan usaha pembibitan sapi ideal di beberapa daerah sentra sapi perah pemerintah bisa membantu para peternak untuk mengatasi masalah - masalah yang dihadapi khususnya masalah bibit sapi baik secara kuantitas maupun kualitas. Dengan adanya kebijakan ini pemerintah bisa mengurangi biaya yang berkaitan dengan masalah pembibitan yang pada akhirnya bisa membantu para peternak secara nyata untuk meningkatkan produksi susu segar baik secara kualitas maupun kuantitas untuk pemenuhan kebutuhan IPSakan bahan baku susu siap minum.

Pemerintah juga seharusnya mendorong usaha swasembada susu dengan kegiatan dan kebijakan yang terintegrasi dari hulu hingga hilir. Pemerintah seharusnya membuat sistem kelembagaan yang tidak hanya berstandar pada kegiatan ekonomi belaka tetapi juga pada kegiatan sosial dengan memperhatikan lembaga-lembaga yang terkait industri persusuan baik dari peternak, koperasi sebagai lembaga perantara anatara peternak dan IPS, serta IPS.

IPS sebagai badan usaha yang menyerap sebagaian besar dari produksi susu lokal haruslah diberikan kebijakan yang mendorong usaha mereka untuk berdaya saing dengan produk susu impor oleh pemerintah. Dengan IPS yang mampu berdaya saing, diharapkan IPS bisa membantu pemberdayaan peternak dan bekerja sama dengan pemerintah dalam hal pembimbitan, pembinaan peternak dalam hal manajemen pengelolaan ataupun manajemen pengelolaan kesehatan serta pengendalian penyakit ternak, serta pengadaan pendidikan dalam peningkatan kemampuan para peternak dengan mengadopsi sistem yang lebih maju dari negaranegara sentra susu dunia.

Bicara mengenai peternakan susu nasional tidak lepas dari peranan koperasi peternak susu, yang sedari awal menempatkan posisi mereka sebagai mediator antara IPS dan peternak sapi perah sebagai produsen dengan harapan bisa memperhatikan nasib para peternak.

Sebagai lembaga mediator koperasi peternak susu tidak terlepas dari masalahnya sendiri. Masalah yang kerap dihadapi oleh Koperasi peternak susu dari sisi kelembagaan, sebagian besar 
peternak sapi perah yang ada di Indonesia merupakan anggota koperasi susu. Koperasi susu sangat menentukan posisi tawar peternak dalam menentukan jumlah penjualan susu, waktu penjualan, dan harga yang akan diterima peternak. Peranan koperasi sebagai mediator perlu dipertahankan.

Permasalahan lain yang dihadapi peternak adalah besarnya ketergantungan peternak terhadap industri pengolahan susu dalam memasarkan susu segar yang dihasilkannya. Keadaan ini diperparah belum adanya kebijakan yang benar-benar berpihak pada peternak, hal ini menimbulkan kecenderungan bahwa harga susu segar yang diterima peternak relatif rendah.

Struktur pasar oligopsoni yang mewarnai hubungan antara para peternak dengan IPS terus menekan para peternak yang mendudukkan mereka pada posisi tawar yang rendah dengan adanya pemberlakuan standar bahan baku yang ketat oleh kalangan industri pengolah susu. Selain harga susu yang sangat murah pada struktur pasar tersebut, tekanan yang diterima peternak semakin bertambah dengan adanya retribusi yang diberlakukan oleh kebanyakan
Pemda di era otonomi daerah ini dan koperasi sebagai lembaga mediator tidak memiliki posisi tawar yang kuat untuk membantu para peternak sebagai anggotanya.

Bagi koperasi, pemerintah harus lebih mendaya gunakan mereka sebagai lembaga yang melindungi serta menyerap produk awal dari peternak dan menyalurkannya pada IPS. Koperasi harus dilindungi dengan sistem tata niaga yang baik oleh pemerintah. Pemerintah bisa memanfaatkan kedekatan emosional dan kultural serta sosial antara peternak dan koperasi untuk memaksimalkan potensi peternakan sapi perah untuk meningkatkan kesejahteraan para peternak dan pemenuhan kebutuhan IPS ataupun produsen produk olahan susu skala lokal yang pada akhirnya bisa memenuhi kebutuhan protein masyarakat sehingga bisa meningkatkan kualitas masyarakat Indonesia.

Peternak sebagai komponen penting dalam sistem agribisnis sektor peternakan khususnya peternakan susu perah harus dilindungi dengan kebijakan yang bisa menguatkan mereka sebagai sumber daya potensial dalam perekonomian. Salah satu caranya adalah dengan membangun 
kelembagaan pangan yang sinergis menuju swasembada susu yang menempatkan peternak sebagai salah satu objek bukan hanya sebagai objek "sapi perah" sistem yang lebih berpihak pada pihakpihak kuat dalam industri persusuan nasional. Dengan sistem kelembagaan yang baik dimungkinkan pemerintah bisa membantu peternak untuk mengatasi masalah yang selalu dihadapi seperti masalah permodalan, harga susu, pembibitan, pakan ternak baik berupa konsentrat maupun hijauan, penyakit ternak, lahan untuk pengembangan peternakan baik untuk membangun kandang dan penyedian pakan hijauan bagi ternak.

Untuk masalah keterbatasan modal peternak pemerintah bisa membangun kelembagaan ekonomi khususnya kebijakan yang terkait dengan kegiatan perbankan dalam penyedian modal baik berupa kredit usaha atau kredit mikro yang kisaran bunganya masih bisa di jangkau oleh peternak dan membuat kebijakan yang memungkinkan para peternak bisa menjaminkan sapinya untuk mendapatkan pinjaman sebagai bentuk koleteral baru.
Pemerintah bisa melalukan proteksi untuk melindungi harga jual susu segar lokal pada IPS, sehingga tidak terjadi penentuan harga susu sepihak oleh IPS tanpa memperhatikan harga produksi yang makin mencekik para peternak. Harga produksi makin meningkat dari hari kehari karena sudah tidak ada subsidi dari pemerintah di produk makanan konsentrat ternak, belum lagi masalah lahan untuk pakan hijauan yang makin sulit di dapat.

Apabila ada kawan khusus atau terintegrasi bagi peternakan pasti tidak akan sulit untuk mendapatkan pakan hijauan untuk ternak karena dengan kawasan terintegrasi memungkin untuk para peternak membagi lahan untuk hijauan sehingga ketersedian pakan bagi para kelompok peternak terjaga dan bisa menghemat biaya transportasi karena lahan hijauannya mudah dijangkau oleh para peternak serta memudahkan proses pengawasannya.

Melalui pengembangan kapasistas kelembagaan ekonomi dan sosial serta penguatan sumber daya manusia pemerintah bisa membantu para peternak melalui program terpadu dalam pelatihan dan pendidikan yang mengacu pada 
pengelolaan peternak yang
berkesinambungan,
membantu perta
berbagai riset untuk menemukan
produk dan bibit sapi unggulan yang
bisa bersaing dalam produksi baik
secara kualitas maupun kuantitas. secara kualitas maupun kuantitas. Dengan kegiatan riset yang baik pemerintah juga bisa mengendalikan kesehatan dan penyakit menular yang biasa menjangkiti sapi perah dan bisa menurunkan produksi baik dari segi kuantitas maupun kualitas yang makin menyudutkan para peternak dalam menghadapi era globalisasi saat ini.

Pemerintah juga bisa membantu peternak dengan membuat sistem kelembagaan terpadu yang mensinergikan kerja sama antar departemen dan lembaga negara. Pemerintah bisa membuat kebijakan yang mengatur kerja sama antara departemen pertanian, departemen, perindustrian dan departemen perdagangan dalam hal pakan konsentrat ternak. Pakan konsentrat yang dibutuhkan oleh peternak adalah pakan dengan harga terjangkau dan mutu yang baik sehingga bisa menghasilkan produk susu segar yang berkualitas.

Pengaturan kerjasama yang dapat dibuat pemerintah adalah dengan mengkoordinakan ketiga departemen tersebut untuk menjaga kestabilan harga pakan di pasaran, walaupun para peternak berharap pemerintah bisa kembali memberikan subsidi pada pakan ternak seperti sebelum adanya Washington Consensus.

Departemen pertanian juga bisa bekerja sama dengan pihak departemen perindustrian untuk membuat peraturan serta pengaturan mengenai pembelian bahan baku makan konsentrat dari industri makanan seperti industri mie dan terigu. Pemerintah melalui kedua departemen itu bisa mengatur harga yang harus diberikan oleh industri terigu dan mie pada ampas atau limbah dari hasil produksi mereka yang berupa serat dari gandum , jagung, dan tapioka bisa dijual murah ataupun diberikan gratis sebagai bentuk CSR kepada koperasi peternak susu.

Pengolahan limbah industri mie dan terigu oleh koperasi bisa lebih efektif dan efisien apabila departemen pertanian membantu memperkenal teknologi tepat guna untuk mempermudah pengolahan bahan baku menjadi pakan konsentrat dengan kualitas pakan yang baik dan bisa mengurangi 
biaya produksi dan bisa memberikan harga pakan yang terjangkau oleh peternak dan memungkin koperasikoperasi memberikan cuma-Cuma bagi para anggotanya sebagai bentuk pelayanan.

Ketiga departemen diatas juga bisa membuat peraturan yang mengikat industri pembuat pakan ternak untuk memberikan harga jual pakan konsentrat sesuai dengan kemampuan rata-rata para peternak, dan memberikan arahan untuk membuat pakan konsentrat dengan mutu yang tetap terjaga walaupun harga jualnya di tekan. Pemerintah juga bisa memberikan reward bagi industri pengolahan pakan ternak dengan pengurangan pajak apabila mereka bisa menekan harga jual pakan konsentrat pada para peternak.

Pemerintah juga harus melembagakan proses standarisasi bibit sapi dengan mutu yang terjamin yang di dapat dari kredit usaha pembibitan sapi (KUPS) harus diatur oleh pemerintah untuk membantu para peternak dalam mengahadapi masalah pembibitan dan keberlanjutan jumlah populasi dan prosuksi. Pemerintah juga bisa memanfaatkan departemen keuangan untuk membuat suatu kebijakan kredit dengan sistem koleteral yang berpihak pada para peternak seperti sistem penjaminan sapi untuk mendapatkan kredit sebagai sistem koleteral baru.

Masalah kredit menjadi penting karena masalah pembibitan peternak selalu berafiliasi langsung dengan keterbatasan modal mereka, dengan adanya sistem kredit yang berpihak pada peternak dan memudahkan mereka untuk terus menjaga keberlangsungan peternakan mereka, dari situ mereka juga akan bisa menambah terus jumalh produksi susu mereka yang bisa membantu keberlangsungan hidup koperasi peternak susu dan IPS.

Sudah seharusnya besarnya omzet dari susu ini seharusnya jadi perhatian pemerintah bahwa bisnis ini menjadi andalan banyak orang dan bisa terus berkembang kalau memang ada kebijakan serius, sehingga bisa mengembangkan usaha peternakan susu nasional dan membawa Indonesia ke swasembada susu.

Pembuatan kebijakan baru yang membantu peternak lokal ini harus di dukung oleh kebijakan yang dibuat Pemda tetati tidak tumpang tindih untuk membantu peternak dalam hal pelayanan kesehatan ternak dan imsemnasi 
buatan untuk menjaga populasi sapi perah sehingga produksi lokal bisa memenuhi kebutuhan bahan baku bagi IPS yang akhirnya bisa meningkatkan kesejahteraan peternak.

Draf abstrak kebijakan ini tidak bisa disimulasikan karena dalam pembuatan kebijakan diperlukan waktu yang tidak sebentar dan harus dilakukan observasi dan penelitian oleh pihak pemerintah untuk membuat draf kebijakan yang diserahkan untuk DPR untuk mendapat pengesahan.

\section{KESIMPULAN}

Untuk memberdayakan usaha peternakan susu lokal pemerintah haruslah memberikan dukungan nyata kepada para peternak dengan membuat kebijakan yang memperkuat kelembagaan ekonomi sosial yang kuat serta bersinergi dan seyogyanya diikuti dengan aktivitas nyata berupa bantuan antara lain dalam bentuk pelatihan dan penyuluhan budidaya sapi perah yang baik, mendorong tersedianya bibit sapi unggul, kemudahan untuk pemanfaatan lahan, akses dan ketersediaan modal bisa dengan menggunakan skema kredit baru yang menggunakan sistem koletral baru dimana memperbolehkan peternak untuk menggunakan sapinya sebagai jaminan, serta pengembangan beragam industri pengolahan susu sehingga harga di tingkat peternak menjadi relatif lebih stabil.

Kebijakan yang dibuat pemerintah seharusnya bisa meningkatkan secara khusus posisi tawar peternak sapi perah dan pengembangan agribisnis berbasis peternakan secara umum dalam menetapkan harga jual susu pada IPS agar sesuai dengan harga produksi. Untuk mencapai posisi tawar yang baik pemerintah harus memperkuat kelembagaan ekonomi dan sosialnya sebagi modal untuk menciptakan peternak sapi perah yang berdaya saing.

Kebijakan yang mengatur kelembagaan ekonomi dan sosial yang berkaitan erat dengan usaha peternakan harus segara disinergikan dalam berbagai macam bentuk peraturan dan pengaturan yang berkaitan dengan usaha peternakan susu nasional sebagai syarat menuju swasembada susu.

\section{DAFTAR PUSTAKA}

Coase, R. 1960. The Problem of Social Cost. Journal of Law and Economics 3, No 1:1-44 Coase, 1988 
Furubotn, E. G and R. Richter. 2000. Institution and Economic Theory. The Contribution of the New Institutional Economics. Ann Arbor. The University of Michigan Press. 2000

Granovetter, Mark.1985. Economic Action and Social Structure: The Problem of Embededdedness. American Journal of Sociology, Volume 91 , Isssue 3

Granovetter, Mark, 2002 A Theoretical Agenda for Economic Sociology, New Directions in Economic Sociology, edited by Mauro F. Guillen, Randall Collins, Paula England, and Marshall Meyer. New York: Russell Sage Foundation, 2002

Granovetter, M. 2005. The Impact of Social Structure on Economic Outcomes. Journal of Economis Perspectives. Vol. 19. Number 1.

Hutagoal,M.P dan F.W Karo-Karo. 2008. Analisis Daya Saing Koperasi di Era Globalisasi: Studi Kasus pada Koperasi Susu di Jawa Barat. Penelitian Kerjasama antara Kementerian

Negara
Koperasi dan UKM RI dan Institut Pertanian Bogor. Deputi Penelitian dan Sumberdaya, Kementerian Negara Koperasi dan UKM RI, Jakarta

Lilis Nulina. 2005. Pemberdayaan Peternak melalui Pengembangan Koperasi Agribisnis Peternakan Sapi Perah. Universitas Pajadajaran.Bandung)

Lin, N. 2000. Inequality in Social Capital. Contemporary Sociology. Washington: Nov 2000. Vol. 29 p: 785, 11 pgs 2000 Nee, Victor, "The New Institutionalisms in Economics and Sociology," in Smelser J. Neil and Richard Swedberg (eds), in the Handbook of Economic Sociology. Princeton University Press, 2005

North, D. C. 1990. Institutions, Institutional Change and Economics Performance. Cambridge University Press 1991

Ostrom, E. 1990 Governing of the common. The Evolution of Institutions for Collective Action. Cambridge University Press. 1990 
Sarker, Debnarayan and Ghosh, Bikash K. 2010. Economic Annals, Volume IV, No. 187 / October - December 2010 UDC: 3.33 ISSN: 0013-3264

Uphoff, N. 2002. Building Partnership with Rural Institutions in Developing Local Capacity for Agricultural $\mathrm{R} \& \mathrm{D}$. In
Capacity Development for Participatory Research. International Potato Center. Los Banos, Philippines 2002) Williamson, O.E. 2000. The New Institutional Economics: Taking Stock, Looking Ahead. Journal of Economic Literature. $\quad$ Vol. 38 